Historic, archived document

Do not assume content reflects current scientific knowledge, policies, or practices. 

62,37






\section{TO OUR PATRONS}

\section{To Be Read Before Ordering}

\section{Non Warranty}

We wish it to be distinctly understood that, while we take every precaution to have all plants and bulbs true to name, we give no warranty, express or implied, as to description, quality, productiveness, or any other matter, of any of the plants or bulbs we send out, and will not in any way be responsible for the crop. Every order we receive will be executed on these conditions only, and they must be accepted by the customer when ordering.

We aim to get new customers and keep old ones, and by honorable dealing to satisfy both customer and ourselves.

\section{Reservation of Plants for Future Shipment}

While we try as far as possible to reserve plants on orders placed in advance for future shipment, it must be borne in mind that plants are perishable and cannot always be held in stock like other merchandise.

Weather conditions frequently make such reservations impossible, as much as we would desire to do so. Customers may rely on us doing our utmost to fill all orders placed in advance, but if we fail we assume no responsibility, and advance orders are accepted on these conditions only.

\section{Safe Arrival Guaranteed}

We guarantee the safe arrival of all goods sent by mail or express to points within the United States. If packages sent by mail or express are lost, we replace them as soon as we are informed of the fact. All claims for damages must be made on receipt of goods.

We do not hold ourselves responsible for failure after goods are delivered in good condition.

\section{Plants Delivered Free}

All plants offered in this catalog at single and dozen rates will be delivered free except large Ferns and Palms, and other large orders which, by their nature, must be sent by express, when they will be sent express collect; that is, the customer will pay express charges. Part of the soil will be removed from all parcel post and prepaid express orders.

\section{Cash With Order}

Please send remittance sufficient to cover entire order. We decline to send goods "Collect on Delivery." If order cannot be filled all noney will be returned. We make no charge for packing and delivering to express or post-office.

R. VINCENT, Jr. \& SONS CO. 


\section{FERNS}

These beautiful and graceful plants now occupy first place among decorative plants. They are unsurpassed for either parlor or conservatory decoration, and nothing gives a touch of refinement to a porch or sun parlor that a well finished Fern does. The Nephrolepsis family, of whichh the well-known Boston and its descendants are members, are of a strong, healthy nature and succeed well under ordinary care. Fine exhibition specimens can be grown in the home.

BOSTON - Nephrolepsis Exhaltate Bostoniensi ;, is a rapid grower of easy culture, soun forming fine graceful plants, its beautiful broad fronds often obtain length of five feet, they droop gracefully, completely hiding the pot or jardiniere. No plant ever introduced has had a larger sale or held its position in popular favor like the Boston fern.

4 -inch $\$ 0.50 \quad 5$-inch $\$ 1.00 \quad 6$-inch $\$ 1.50$ Large specimens 8- and 10-inch $\$ 10.00$ to $\$ 15.00$ each.

SCOTTII-The fronds are broad and beautifully tapered from base to tip. They droop just enough to make a shapely graceful plant and to finish with a nice full centre. It is such a compact vigorous grower that it thrives well under rather adverse conditions, producing a plant of rare beauty and perfection, indispensable for dining-room or library, or places in the home where room is somewhat limited.

4 -inch $\$ 0.50 \quad 5$-inch $\$ 1.00 \quad 6$-inch $\$ 1.50$ Large specimens from $\$ 5.00$ to $\$ 10.00$ each

CORDETTA COMPACTA-This is better known as the sword plant, its fronds are rather more narrow than the Scottii and stand erect more than drooping. 'They are dark holly gree. and have the strongest constitution of any of the decorative ferns, will last longer and keep better than any other kind, in fact many people who through adverse conditions have difficulty in growing the Boston type succeed well with this.

4 -inch $\$ 0.50 \quad 5$-inch $\$ 1.00 \quad 6$-inch $\$ 1.50$

WHITMANII-The Ostrich Plume fern is a sport from the Boston fern. The ends of the pinnaes which overlap on the heavy fronds are sub-divided and twisted, giving it an attractive, airy and feathery appearance.

4-inch $\$ 0.50 \quad 5$-inch $\$ 1.00 \quad 6$-inch $\$ 1.50$

HOLLY FERNS-Cyrtonun Rockfordiaum -This is one of the most beautiful ferns to use either as a small plant for table decoration, or to grow into specimen plants. Its foliage is dalk gloss $y$ green, in shape and color very much resembling the holly foliage. They are used extensively for table decorations at Christnias time, with sprays of berried holly stuck in the pa:ıs.

3 -inch $\$ 0.30$ each

4 -inch 0.50 each

5 -inch 1.00 each

\section{PALMS}

BELMORIANA - A handsome spreading specimen, fine, rich dark green foliage, which curves gracefully with a grandeur and decorative effect hard to describe. This variety is grown only one plant to a pot or tub. 4-inch pot, $\begin{array}{ll}\$ 0.75 & 5 \text {-inch pot, } \$ 2.00 \\ 6 \text {-inch pot, } \$ 4.00\end{array}$

7-inch tubs, 32 to 34 inches high, $\$ 6.00$ 8 -inch tubs, 36 to 40 inches high, $\$ 10.00$ Large plants up to $\$ 15.00$ each.
FOSTERIANA-This variety is similar to Belmoreana, but a stronger grower and heavier foliage. They are grown in made-up plants; that is, four plants are planted together in a tub, this makes large and heavy effect for decoration.

7-inch tubs, 30 inches high, $\$ 6.00$

7 -inch tubs, 36 inches high, $\$ 8.00$

7 -inch tubs, 40 inches high, $\$ 10.00$

8 -inch tubs, 48 inches high, $\$ 12.50$ 


\section{ABUTILON}

Flowering Maple. The plant grow rapidly and flower freely and by some are considered indispensable for winter blooming; planted out in the Spring they are effective for bedding or borders.

$$
20 \text { cents each. } \quad \$ \text {. } 50 \text { per doz. } \quad \$ 8.00 \text { per Ioo. }
$$

ECLIPSE-Mottled green and yellow foliage, scarlet bell shaped flowers. Dwarf growing, suitable for window boxes and low bedding; makes a pretty winter blooming plant.

\section{ACALPHA-MACAFEEANA}

A tall growing plant used extensively for large bedding and border for Canna beds. Can be used among shrubbery for color effect. The foliage is handsome in its coloring, being a combination of bright red and yellow, mottled with chocolate. 20 cents each.

$\$ 1.50$ per doz.

$\$ 8.00$ per 100.

\section{ACHYRANTHES}

These are handsome bedding plants that should be more used. They are taller growing than Alternantheras and will stand trimming in shape better than Coleus. The colorings are strikingly beautiful and stand out in distinct contrast when properly planted.

$$
\text { zo cents each. } \quad \$ \text { I.50 per doz. } \quad \$ 8.00 \text { per Ioo. }
$$

BESTERI MOSIACA-Light green and GIBSONII-Pointed leaf, green with yeldark red mottled foliage.

BLARDII-Pointed, broad leaf of purplish crimson.

EMERSONII-Round, broad leaf of purplish crimson.

low marking.

LINDENII-Color dark purple, with narrow pointed leaves. The popular dark red bedding variety.

McNALLY-Round, broad leaves, green streaked yellow.

\section{AGERATUM}

One of the best bedding plants, as they can be depended on to bloom continually during the summer. The blue varieties are particularly valuable on account of a scarcity of this color among our bedding plants; also very satisfactory as a pot plant, the best results being obtained when the plants have become pot-bound. They should be started early enough to be headed back to make them bushy.

$$
20 \text { cents each. } \quad \$ 1.50 \text { per doz. } \quad \$ 8.00 \text { per IOO. }
$$

LITTLE GEM-Dwarf blue.

MRS. ALFRED EHMANN-Low plants, free flowering, blue.

PRINCESS PAULINE-Sky blue, white centre.
TRIOMPHE DES PARTERRES-Beautiful variety; Russian blue, strong, robust grower.

STELLA GURNEY - Dwarf, compact grower; large flowers, azure blue.

\section{AGERATUM-FRASERII}

We feel confident in offering Ageratum "Fraserii" to our customers that we are offering what will be one of the most valuable acquisitions to the bedding plant 


\section{AGERATUM-FRASERII-Continued.}

line in recent years, that is a blue, a decided blue, that would be continually in bloom. In our trial grounds last summer "Fraserii" attracted more attention than any other bedding plant. It only grew about eight to ten inches high and was covered the entire summer with what can easily be classed as immense truss of flowers, as many of them were over two and one-half inches across, while the individual flower would be seven-eighths of an inch in diameter. The plant spread about twelve to fifteen inches across. It can very easily be used with Alternantheras as a border plant. plant.

Being an early bloomer and dwarf, compact grower, it makes an excellent pot

$$
25 \text { cents each. } \quad \$ 2.50 \text { per doz. } \quad \$ 15.00 \text { per IoO. }
$$

\section{ALTERNANTHERAS}

The most used and most satisfactory bedding plant that we have for lettering, design work and low bedding. The dwarf varieties grow eight to ten inches high and ten to twelve inches wide, requires very little trimming to keep it in shape.

\section{$\$ 1.00$ per doz. $\$ 6.00$ per roo.}

AUREA NANA-Yellow, compact. BILLIANTISSMA-Rich carmine.

CARROLL PARK BEDDER-Dwarf red. JEWELL-Rich carmine; strong, robust. SEYBOLDII-Yellow; strong grower.

VERSICOLOR-Crimson, chocolate and green: tall grower.

CARROLL PARK BEDDER-Red fringed with yellow and scarlet.

\section{ALYSSUM}

DWARF_-The dwarf Alyssum is used for low borders, vases, baskets, rock-work, etc., producing a continuous succession of small white flowers. It is also the best for pot culture.
GIANT-The tall, or Giant, is useful for vases, window boxes, etc., where a drooping effect is desired. It is also very useful as a winter cut flower, blooming continually the whole season. It does best in a carnation temperature. 20 cents each. $\$ 1.50$ per doz. $\$ 8.00$ per 100 .

\section{BEGONIAS}

Begonias can be adapted to almost any use to which a blooming plant can be used. As a pot plant it is superb; as a bedding plant it cannot be excelled. They are continuously in bloom the entire summer season, and as a house plant they can be depended upon to bloom as long as desired.

"PRIDE OF NEW CASTLE"-A red sport of Glorie de Chatelaine, possessing all the characteristics and habits of this favorite variety. The color is a deep rich Begonia red.

25 cents each. $\$ 2.50$ per doz.

GRACILLIS ROSEA-Handsome flower of a delicate rose color.

LUMINOSA-Red flower; foliage turning reddish bronze when growing in the sun.
GRACILLIS PFITZERI TRIUMPH-Pure white, free flowering.

GLORIE DE CHATELAINE - Dwarf, compact grower. Always full of flowers of a lively pure pink color, a good hardy grower. This is becoming a popular pot and bedding plant.

20 cents each. $\$ 1.50$ per doz. $\$ 8.00$ per 100 


\section{R.Vincent, Jr. \& Sons Co.}

\section{CUPHEA}

Cigar Plants. Flowers tubular in shape, $\mathrm{I}^{1 / 2}$ to 2 inches long, and have two bright scarlet wings at the end of each flower The tip of the flower is bright purple, the stamens are pure white. Useful as a basket or pot plant; blooms continuously.

20 cents each. \$I.5O per doz. \$8.00 per Ioo.

\section{CANNAS}

In Cannas we have not tried to offer a large list, which necessitates the duplication of varieties, but rather to offer a list of distinct, dependable varieties. The plants we offer are strong three-inch pot plants, which will make an immediate effect, and should not be planted until all danger of frost is over. Unless otherwise noted, the price is 25 cents each, $\$ 1.50$ per doz., $\$$ IO.OO per IoO.

ALPHONSE BOUVIER--Crimson; five feet CITY OF PORTLAND-A wonderfully deep rosy salmon, color much richer than Mrs. Alfred Conard; the flowers are of a large size, abundantly produced in large trusses. 50 cents each. $\$ 6.00$ per doz. $\$ 25.00$ per 100

GLADIATOR-Strong, vigorous grower, with fine green foliage; large heads of flowers; color is yellow spotted with rel; blooms early and late, always looks cheerful.

GUSTAV GYMPPER-This is an ideal rich yellow bedding Canna, the flowers of good size are held well above the foliage. The color is a rich golden yellow, a shade that can be seen as far as the eye can carry.

J. D. EISELE-Brilliant vermilion, scarlet, three and one-half feet.

KING HUMBERT-In this we have the finest type of orange scarlet flowers combined with the finest type of bronze foliage. 25 cents each. $\$ 2.50$ per doz. $\$ 10.00$ per 100

MAROS-The best white flowering Canna. Its flowers of creamy white are produced very freely on stems thrown well above the foliage.

MME. CROZY-Popular and valuabla; rich orange scarlet flower, edged with bright golden yellow. Four feet.
THE PRESIDENT-The flowers are produced in immense trusses of the most brilliant red, it possesses all the good points of Fire Brand enhanced by extraordinary vigor and perfectly healthy foliage.

50 cents each. $\$ 3.50$ per doz.

$\$ 25.00$ per 100

PRESIDENT MYERS - Rich, carmine flowers, bronze foliage, four feet.

QUEEN CHARLOTTE-Rich pomegranate red, bordered with bright golden yellow.

RICHARD WALLACE - Gre n foliage, large canary yellow flowers. $4 \frac{1}{2}$ feet.

ROSEA GIGANTEA-Rich rose-pink flowers, dark foliage, four feet. 35 cts. each. $\$ 2.50$ per doz. $\$ 15.00$ per 100

RUBIN-Bright scarlet flowers, dark foliage. Four feet.

SOUV. d'ANTOINE CROZY-Beautiful red, bordered with golden yellow.

UNCLE SAM-Clear, deep orange flowels, borne in large clusters, handsome, luxuriant, rich green foliage. Six feet.

VENUS-The color is a gay rose-pink with mottled border of creamy white.

WYOMING-Orange-scarlet flowers; dark foliage. Four and one-half feet.

\section{CHRYSANTHEMUMS}

These are universally popular for bedding as well as for cut flowers. No collection of Chrysanthemums is complete without some of them, and, considering their 


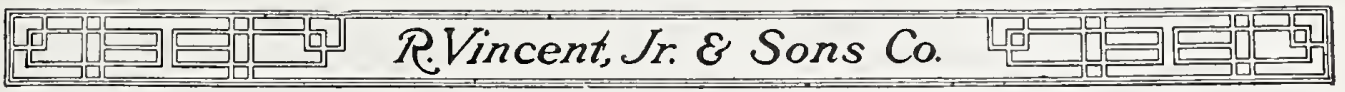

\section{CHRYSANTHEMUMS-Continued}

many qualities, there is no cause for surprise to see them cultivated so extensively. Plants from 2-inch pots, Io cents each, $\$$ I.00 per doz., $\$ 6.00$ per Ioo.

\section{Large Flowering or Aster Varieties}

These are not the large flowering or exhibition varieties, but the large flowering Hardy Chrysanthemums which will make flowers about two to three inches in diameter. For cut flowers the best results are obtained by a slight disbudding, leaving from six to eight flowers on a spray. They should also be somewhat protected from the frost when desired for cutting.

ASBURY-Sulphur-white, for cut flowers. BRADSHAW-Lilac rose, cut petals.

DAISY ANDERSON-Reddish bronze, dwarf.

ELDORADO_Bright golden yellow, open Center.

ELKTON_Light pink; full, large flower. EXCELLENCE-Pure white, tall grower.

EXCELSIOR-Bright orange yellow, long stem.

FRED J.-Red orange, good for cut flowers.

GERMANIA-Large flower, straw white, long stem.

GERTRUDE-Pure white open center.

HESTER-Pearl white, shaded pink.

IRENE-Pure white, dwarf, early.

JERRY-Rose lilac, open center.

JERSEY-Pure white, open center.

KING HENRY-Straw white, long stem.

LELIA-Bright rich red.
LORLEY_Large full flower; y e 11 ow, tinged pink.

MARIANA-Snow white, large flower on long stem.

MISS JULIA-Orange red, turning yellow.

PRINCE of WALES-Snow white, long stem, fine for cutting.

QUEEN of WHITE-Fine creamy white, long stem.

REV. W. H. HOFFMAN-Golden bronze, long stem.

SIR MICHAEL-Lemon yellow, open center, long stem, for cut flower.

SYLVIA-Scarlet bronze, tall grower.

SUSQUEHANNA-Clear lemon yellow, tall g'rower.

TRIOMPHE D'OR-Rich golden yellow.

URITH-Bronze, tipped yellow, large flower, broad petals.

VIOLA-Rich violet rose.

WINDLESS-Rich golden yellow, large flowers.

\section{Small Flowered or Button Varieties}

The small flowering or button varieties are most suitable for borders and uutdoor blooming, as the flowers are not easily damaged by frost. The flowers of these are usually two inches or less in diameter, Baby and other small varieties only being about three-quarters of an inch in diameter. Grown as cut flowers they are very effective when used with large flowers. Florists find that a few of them add a great deal to the appearance of a box or spray of specimen flowers.

ANNA MARY - Creamy white, shaded pink.

HILDA CANNING-Bright bronze, long stem for cutting.

INEZ-Scarlet bronze and rose.

JAMES BOONE-Pure white.
LITTLE GEORGE-Violet red.

LITTLE PET-Rich violet rose.

NELLIE RAINSFORD-Light pink, very dwarf.

YELLOW BABY-Smallest yellow.

YELLOW GEM-Golden yellow. 


\section{CHRYSANTHEMUMS-Continued.}

\section{Anemone Varieties}

The Anemone varieties are so-called from the arrangement of the inner petals, resembling the Japanese Windflower. The flowers are about two to two and one-half inches in diameter. When grown for cut flowers should be protected from heavy frost.

BARNEY-Golden bronze, dwarf, suitable for pot culture.

EARLE-Pearl white, silver-rose center, dwarf.

EVA- Rose pink.

GOLDEN LYDIA THOMAS-Golden yellow, heavy center.
LADY OLIVIA-Beautiful white.

MATILDA-White large flowers.

MAY SUYDAN-Bronze large flower.

MYER'S PERFECTION-Fine pure white, tall grower, good for cutting.

PALMYRA-Silver pink, long stem.

\section{COLEUS}

The Coleus is a plant familiar to all; for bedding purposes it cannot be excelled. The foliage is very beautiful and in a great variety of shades of markings, yellows and red predominating. It is used in great quantities in private places, public gardens and parks. The Coleus shows up best and makes the best showing when planted in color masses, light and dark colors contrasting. Coleus requires full sunlight to bring out its brightest colors.

$$
20 \text { cents each. } \quad \$ 1.50 \text { per doz. } \quad \$ 8.00 \text { per roo. }
$$

BRILLIANCY - This variety belongs to the Giant leaf section; of strong vigorous habit growing from 2 to 3 feet high; leaves often from 9 to 19 inches long which are of a bright carmine, shading off to a deep maroon, the margin being yellow and green, the whole leaf having a rich velvety lustre.

\section{STANDARD VARIETIES}

ANNIE PFITZER-Very dwarf; yellow.

BECKWITH GEM-Magnificent scalloped edge, center bright, soft crimson maroon, bordered with a gorgeous combination of green and gold.

DUNERIA-A magnificent Coleus; color, various shades of crimson, with leaves very large; a magnificent showy bedder, standing the sun as well as Verschaffeltii.
DAZZLING GEM-Rose-pink center, margin of choculate green. Dwarf compact grower. Stocky por plant variety.

ELDORADO-Luxuriant, velvety foliage; old gold handsomely ribbed and blotched very dark garnet.

FIRE BRAND-Bright maroon; charmingly flamed and shaded, vividly glowing scarlet of wondrous beauty.

GOLDEN BEDDER-This indispensable and favorite yellow bedder needs no description.

HERO-The model of perfection in dark colors, almost jet black leaves, pointed and scalloped; a remarkaily handsome variety.

JOHN PFITZER-Dwarf, compact grower, reddish crimson edged with yellow

LORD PALMERSTON - An excellent, beautiful, dark velvety maruon center, with dark crimson ribs, commanding admiration from all. 


\section{COLEUS-Contined.}

LYONS-A beautiful yellow variety, with handsome markings, a good bedder and quite distinct.

MRS. HAYS - Colors and shades are wonderful; lovely, bright golden yellow, ribbed and margined velvety crimson.

QUEEN VICTORIA-Remarkably handsome; bright cardinal red, with distinct bright golden border; strikingly beautiful.

ROB ROY-The beautiful dwarf variety, pinkish red, with crinkled edges, winning an enthusiastic admiration for all who see it.

SENSATION-Dark maroon, light crimson with pink ribs and center.
SUN RAY -Dwarf, crin.son center blotched with pink, deep scalloped green and yellow edges.

VERSCHAFFELTII-The standard crimson bedding variety.

TRAILING QUEEN-The so-called running variety, small foliage dwarf grower; yellow and pink center, bordered with maroon and green.

YELLOW TRAILING QUEEN-Center of bright yellow, bordered with olive green, with deeply serrated edges intermingled with yellow. $20 \mathrm{cts}$. each. $\$ 1.50$ per doz. $\$ 8.00$ per 100

\section{DAHLIAS}

The prices quoted are for strong pot-grown plants, which many experienced growers of the finest grade of cut flowers prefer to roots, claiming that they produce a far superior grade of flowers.

The time of planting depends on the location, usually about the time that the vegetables are being planted. For Maryland and vicinity we suggest May 2oth to June 20 th as the proper time.

ABERDEEN-(Cactus) Deep carmine, bright shading carmine.

Each Doz.

A. C. IDE-(Decorative) This is a grand variety and one certain $\$ 1.00 \$ 10.00$ to be in demand, especially for exhibition. It is large, of fine quality and blooms are produced freely. The color is a rich velvety maroon.

A. D. LIVONI-(Show) Rich sea shell pink.

ADOLPH-(Decorative) Crimson Maroon on good stiff stems, well above the folige, good for cutting for decorative purposes.

ALLIE MOUREY (Pompon) Pinkish white, tipped deep pink.

AMI BARRILLET-(Single) Scarlet crimson flowers, dark-bronze foliage.

ATTRACTION-(Cactus) A Beautiful Dahlia that is greatly admired. The flowers which measure fully 6 inches in diameter are composed of gracefully arranged curled or twisted petals of a lively yet soft silvery mauve-rose, with white suffusion.

ALEWINE-(Pompon) Flesh edged lavender pink.

AUGUSTA NONIN-(Decorative) A very large flower of fiery red, very free and borne on long, stiff stems, will prove valuable for cutting or garden decoration.

$.25 \quad 2.50$

$.15 \quad 1.50$

$1.00 \quad 10.00$

$\begin{array}{ll}.15 & 1.50\end{array}$

$.15 \quad 1.50$

$1.00 \quad 10.00$

$.15 \quad 1.50$

$.25 \quad 2.50$

$2.00 \quad 20.00$

$2.00 \quad 20.00$

$\begin{array}{ll}.50 & 5.00\end{array}$

$.15 \quad 1.50$

$.35 \quad 3.50$

$.15 \quad 1.50$ 


\section{R.Vincent, Jr. \& Sons Co.}

\section{DAHLIAS_Continued}

CANTEEN-(Decorative) A fine form of flat decorative flowers of a pretty shrimp pink.

CHESAPEAKE-(Decorative) A peculiarly striped and tinted variety, very attractive. Canary yellow, striped and streaked throughout with crimson the color of the reflex.

COWENTON-(Cactus) Deep velvety maroon, good stems and free bloomer very attractive being such unusual coloring to attract attention at all times.

CONOWINGO-(Cactus) One of the best cactus to date. Outside petals salmon yellow, shading to lemon yellow towards center. Large free bloomer on good stems.

COLGATE-(Cactus) Lemon yellow of fine form and erect growth, good flowers of large size on stiff stems.

CASSANDRA-(Peony) Bright, velvety crimson.

COUNTESS of LONSDALE-(Cactus) Rich salmon.

CHARLES LANIER-(Show) Yellow amber, shaded buff.

CRIMSON QUEEN-(Pompon) Deep crimson shaded purple.

Each

Doz.

$\$ 2.00$

$\$ 20.00$

2.00

20.00

2.00

2.00

1.00

.50

.15

.15

.15

DEADLOCK-(Decorative) One of the best whites yet introduced being a white attraction born on good stiff stems well above foliage, often making flowers from six to eight inches in diameter.

DELICE-(Decorative) Beautiful glowing rose pink; good stems. Fine for cutting.

DIEMONT van BIJSTEIN-(Peony). The petals are most delicate lilac mauve with bluish tints. Flowers are borne on enormous long stems of wiry stiffness, and are produced in great abundance.

DOROTHY PEACOCK-(Decorative). best shell pink. Fine for cutting.

A beautiful show; color

DR. TREVIS-(Decorative). A soft salmon rose, suffused with old gold, with golden apricot at center. The blooms are extra large and borne in profusion on long stout stems. The petals are a rich old rose reflex.

DR. H. SEWALL-(Peony). Broad, flat petals, surrounding a small yellow disc. Color a pink fawn, with slight amber shading at the base of the petals.

DREAM-(Decorative). Amber rose, borne on long stem, which holds the flower free above the foliage; excellent for both cutting and garden decoration.

EDEN-(Collarette). A lovely, pure white collarette, admitted by Dahlia experts to be the finest yet introduced; good bushy habit, free flowering. Height $3 \frac{1}{2}$ feet.

ETHEL MAULE-(Show). Pure white, tinged pale lavender in center; medium size flowers.

EBENEZER-(Decorative). An entirely new type of twisted petaled decorative dahlia. Bright velvety maroon showing a light reflex. Large flower, tall grower a very desirable variety.

EXTREME-(Decorative). A fine erect grover, bearing flowers on erect stems, good cutter, fine deep mauve pink.

5.00

50.00

.15

5.00

50.00

1.00

10.00

FREDERICK-(Cactus). Rich apricot with carmine shading, fine pointed and twisted petals.

FRIDAY-(Decorative). A good bronze decorative, of good form and habit.

FRASER-(Decorative). An extremely good large light pink, good bloomer and very desirable flowers.

FLAMINGO-(Decorative). The flowers held erect on stiff stem of a rich and glowing rose pink, while it frequently shows an open center; this does not detract from its beauty.

FLORA-(Cactus). Large, pure white.
$1.00 \quad 10.00$

$1.00 \quad 10.00$

$3.00 \quad 30.00$

$.25 \quad 2.50$ 
FRANK SMITH-(Show). Dark, rich maroon, tipped white.

FRINGED 20th CENTURY-(Century). Similar to 20th century in color, the petals are deftly cleft, giving it a fringed appearance.

FUTURITY-(Decorative). Similar color to Lyon Rose; flowers very large and freely produced.

GEISHA-(Peony). Rich combination of scarlet and gold, with a yellow center, which becomes suffused with and deepens to scarlet at center, petals shading lighter at edges.

GEN. J. B. SETH-(Cactus). A rich, gorgeous Dahlia of brilliant scarlet shadings; of perfect form held well above the foliage on stiff stems. This variety is a glow of color until the end of the season.

GEORGE WALTERS-(Decorative). Another large flowering Dahlia with extra strong stems. Color, salmon and shrimp pink shades.

GOLDEN GATE-(Catus). Truly a colossal cactus; flowers often measures 9 inches in diameter, full to the center. Petals are of a heavy leathery texture. The color is a bright golden yellow, early and freely flowering, a first class dahlia in every respect.

GOLDEN WEST-(Decorative). Best yellow, good stems, fine for cutting.

H. J. LOVINK-(Peony). Lilac at outer edge, base of petals yellowish, sometimes running in strips through the petals.

HON. R. L. BORDEN-(Peony). Large; distinct, rich golden bronze. One of the finest of recent introduction.

HORTULANUS WITTE-(Decorative). A very large, long stemmed, free-flowering, pure white. A splendid cut flower and exhibition variety.

HORTULANUS FIET-(Decorative). Another giant-flowered variety. The most delcicate shade of shrimp pink, the tips of each petal barely touched with gold. The entire flower has a suffusion of delicate tints of red and yellow, which gives a glow, yet $\mathrm{s}$ ftness of color difficult to describe.

HIGHLAND BEAUTY-(Cactus). Salmon, orange fringed petals, tipped salmon; a very pretty effect; good bloomer.

HOLLYWOOD-(Cactus). A fine form of flower large and free heautiful rich salmon.

INDIAN CHIEF-(Pompon). Crimson.

JACK ROSE-(Decorative). Rich velvety crimson. An ideal cut flower sort.

J. HARRISON DICK-(Cactus). A hybrid Cactus of immense size, which is freely produced on rigid stems. It is an exhibition variety of the highest class. The color baffles successful description, it being a pleasing shade of canary yellow shading through orange, lavender and pink to the outer edges of the petals this Byron rose.

JACK'S DISCOVERY-(Decorative). White, mottled violet rose.

JEAN KERR-(Show). A pure white bloom, carried gracefully well above the foliage. A foremost variety for cut flowers but just as important as a garden variety, due to its compact strong growth and free-flowering habit.

JANE SEHBY-(Decorative) An immense pink decorative of wonderful formation. Flowers are borne on long, stiff stems above the foliage.
Each Doz.

$\$ .15 \$ \$ 1.50$

.25

.50 
JOAN of ARC-(Decorative). A new variety which has attracted Each Doz. great attention being a beautiful pink of violet and Lilac combination, large and free flowering one of the most profuse bloomers of recent introduction.

JOPPA-(Decorative). Large flowers, held very erect on woody stiff stems, dark salmon rose, combined with apricot and gold flowers, eight to ten inches across.

JUDGE PRESTON-(Cactus). A fine formed flower of narrow petals, good bloomer of a pretty bronze color, born freely on good stem.

JUDGE DUNCAN_-(Decorative). A very pretty crimson maroon flower, sure to please wherever good dahlias are shown.

JUDGE OFFUT-(Cactus). Bright buttercup yellow shading to amber, a peculiar yet pleasing combination, free bloomer.

$2.00 \quad 20.00$

$1.00 \quad 10.00$

$2.00 \quad 20.00$

$2.00 \quad 20.00$

KALIF-(Colossal Cactus). A truly majestic flower, frequently measuring 8 to 9 inches in diameter; a perfest Cactus form in color a pure scarlet.

..

KING of AUTUMN-(Decorative). Large perfectly formed flow-
ers, held erect on stiff stems. The color is a beautiful shade of ers, held erect on stiff stems. The color is a beautiful shade of
burnt amber, tinged and shaded old rose.

KIWANIS-(Decorative). Large incurved and twisted petals, really a new type in Dahlias, of a bright canary yellow, free bloomer, very much admired by everyone.

LAWINE-(Cactus). White showing blush as the flower matures.

LE GRAND MANITOU-(Decorative). Large white flowers, streaked violet purple.

LITTLE BEAUTY-(Pompon). Delicate shrimp pink.

LITTLE MAY-(Pompon). Bright lemon yellow.

LYNDURST-(Decorative). Intense, rich, vivid, scarlet.

LENORE-(Decorative). A fine form, lemon yellow with a pretty rosy reflex good for cutting.

$\$ 5.00$

5.00

50.00

.15

1.50

2.50

.15

1.50

.15

1.50

.15

1.50

1.00

10.00

MT. MORIAH-(Cactus). Large amber, shading to salmon pink, a beautiful combination.

MT. VERNON-(Decolative). A good size fine blooming pure yellow one of the best yellows in this class.

MT. ARARAT-(Cactus). A beautiful bright salmon flesh blended pink making a fine cut flower.

MABEL-(Decorative). Light mauve, very pretty and free flowering good stems.

MAD. A. LUMIERE-(Decorative). Pale white, violet red points.

MARGUERITE BOUCHON-(Cactus). Magnificient shade of brilliant, yet soft rose, with very large white center and distinctly fine white tips.

MAURICE REVOIR-(Collarette). Blood red, with a pure white collar.

MERRITT-(Decorative). Said to be the best of recent introduction in any class or color. Lemon yellow on long stems prof use
bloomer of fine habit of growth. Good for exhibition or commercial purposes.

MEYERBEER-(Peony). Pure lined crimson, very strong stems, the largest peony Dahlia in commerce; most distinct and striking. 
MINA BURGLE-(Decorative). A rich, luminous dark scarlet, on long stiff stems; splendid both for cutting and garden decoration; free flowering.

MISS MINNIE McCULLOUGH-(Decorative). Soft yellow, overlaid with bronze.

MRS. CHAS. L. SEYBOLD-(Peony). Distinct bright, crimson pink, each petal tipped white. A strikingly beautiful variety.

MRS. J. G. CASSETT-(Decorative). Rose colored, with grand stems and plenty of substance in flowers.

NORTON-Decorative). A good cut flower variety, of a bright fleshy pink.

NANCY MAE-(Cactus). An intense scarlet, with maroon shading; flowers absolutely perfect, borne on stiff, wirey stems; very free. An ideal cut flower.

OREGAN BEAUTY-(Dccorative). An intense oriental red, with golden sheen and garnet suffusion. Large liowers with long stems.

PINK PROFUSION-(Cactus). Thulite pink shading slightly to flesh at center. Early bloomer of fine habit. Dwarf grower and profuse bloomer.

PATAPSCO-(Hybrid Cactus). Six inch flowers, curled and twisted petals, gracefully arranged, deep silvery mauve rose suffused pink, very much admired. Free bloomer and good habit.

PATRICK O'MARA-(Decorative). The flowers are eight inches or more in diamter and borne on long stiff stems. They are firmly set at right angles close to stem. The color is an unusual soft and pleasing shade of orange-buff, slightly tinged with Neyron rose. An Autumn shade that will be in great demand. It is a splendid shipping and long keeping Dahlia. None better for commercial us or more pleasing for ornamental gardens.,

PAPA CHARMANT-(Decorative). Bright, glowing, velvet maroon, large perfectly-formed flowers, on long stiff stems.

PAUL BONYON-(Decorative). A beautiful salmon pink, with a luninous green sheen. The flowers are large, perfect in shape and very freely produced on long stems.

PERLE de LYONS-(Decorative). Pure white.

PLANET-(Cactus). Maroon striped with lavender, sometimes coming in solid colors.

PRAIRIE FIRE-(Peony). Rich scarlet.

PRES. FALLIERS-(Peony). The Color is a most intense red, so vivid as to dazzle the eye, free-flowering and of the finest form.

PRINCE of YELLOWS-(Cactus). A rich, canary yellow. One of the best vellows for cutting.

PRINCESS JULIANA-(Peony decorative). Pure white, perfect flowers, dark green foliage; long, strong stems.

QUEEN MARY-(Decorative). Fine rose pink, free bloomer, good, stiff stems.

QUEEN of YELLOWS-(Show). Pure yellow, quilled petals.

QUEEN WILHELMINA-(Peony). Fine, pure white.

ROSETTAH-(Cactus). An extra good flower, born on wirey stem, good size and quality. Rich deep rosy pink.

ROSSVILLE-(Decorative). Beautiful crimson, magenta, yellow striped center, slightly anemone.

RENE CAYEUX-(Cactus). Rich geranium red.
Each Doz

$\$ .35 \$ 3.50$

.15

.15

1.50

.15

1.50

1.00

10.00

1.00

10.00

30.00

1.00

10.00

2.50

.35

.25

3.50

.25

.15

2.50

2.50

.35

1.50

.15

3.50

.50

1.50

5.06

.15

.15

1.50

1.50

2.50

2.00

20.00

2.00

.15

20.00 


\section{R.Vincent, Jr. \& Sons Co.}

\section{DAHLIAS-Continued}

ROTARIAN-(Decorative). Large curled and twisted petals flowers a mate to Kiwanis of a fine violet maroon extra grod habit of growth and blooming.

ROSE PINK CENTURY-(Century). Clear rose pink; immense size.

\begin{tabular}{rr} 
Each & \multicolumn{1}{c}{ Doz. } \\
$\$ 5.00$ & $\$ 50.00$ \\
.15 & 1.50 \\
& \\
1.00 & 10.00 \\
2.00 & 20.00 \\
.15 & 1.50 \\
& \\
& \\
.25 & 2.50 \\
& \\
.35 & 3.50 \\
.25 & 2.50 \\
& \\
25. & 2.50 \\
.25 & 2.50 \\
.15 & 1.50 \\
.15 & 1.50 \\
.15 & 1.50 \\
& \\
.50 & 5.00
\end{tabular}

SEAPLANE-(Cactus). Large flower long incurved petals of aimost pure white.

SWEETHEART-(Cactus). A heavy pure white; fine twisted and curled petals, free blooming, dwarf habit.

SCARLET CENTURY-(Century). Bright scarlet.

SEBASTAPOL-(Decorative). One of the finest of recent introduction. Flowers rich, bright orange, of good substance, borne freely on long stiff stems. The best in its class and color. Good cut flower.

SEEDLING No. 37-(Peony). The most delicate and tender combinaticn of a soft, rosy lavender, suffused and over-laid silvery fawn.

SENSATION-(Century). A double century. Vivid scarlet heavily tipped white.

SOUVE de C. DOUZON-(Decorative). Enormous orange red flowers.

SOUVE MME. MOREAU-(Show). Deep, rich pink.

SNOWCLAD_-(Pompon). White, and early and profuse bloomer.

STANDARD BEARER-(Cactus). Rich firey red.

ST. GEORGE-(Single). Large; pure yellow.

SULPHURIA-(Decorative). Very clear sulphur yellow: flowers large and shaggy petals, borne on long stems; very free and attractive.

TOWSON-(Cactus). Large loose flowers, petals curling back to stem, forming almost a ball of brilliant scarlet shading. A fine addition to a collection.

TIMONIUM-(Cactus). Very prettily twisted petals of light bronze, fine form, and good stem.

TAFFY-(Decorative). Another good cut flower variety, light rose pink, slightly streaked fleshy yellow, good bloomer.

ULYSSUS-(Decorative). Rich, deep crimson, very fine.

VALENTINE-(Collarette). Yellow shading crimson, white coll irette.

WINDLESS-(Cactus). Amber rose, streaked yellowish amber on good stems and free bloomer.

WEBER-(Peony). Lovely shade of rose pink, fine form and stem.

WARREN S. SEIPP-(Cactus). Spectrum red, shading to carmine towards center, free flowering, good true cactus form and stem.

WHITE CENTURY-(Century). Beatiful snow white.

WM. F. GUDE-(Decorative). Pure white, long stems; good keeper fine for cutting.

WODAN-(Cactus). Bold, large, but not coarse flowers, frequently 7 inches in diameter; a graceful arrangement of semi-curved petals of a pleasing delicate salmon-rose color, shading to old gold in center.

WOLFGANG von GOETHE-(Cactus). Large, gracefully arranged perfect flowers of a rich apricot, with carmine shading.

$1.00 \quad 10.00$

$.50 \quad 5.00$

$5.00 \quad 50.00$

$.25 \quad 2.50$

$.25 \quad 2.50$

YELLOW DUKE-(Decorative). Pure canary yellow.

YELLOW LE COLOSSE-(Decorative). Large, double flowers of brightest yellow. 


\section{DUSTY MILLER}

SENECIO ARGENTEUS-Silvery foliage.

Fine for bedding; vases; hanging baskets and pots; also extensively used for margin.

$\$ 0.20$ each. $\$ 1.50$ per doz. $\$ 8.00$ per 100

\section{GERANIUMS}

We have no hesitation in claiming that our selection of Standard sorts stands preeminent among such collections in the world. It contains only distinct and useful varieties and is the result of the most careful selection of hundreds of varieties introduced by the foremost European and American hybridizers. We have listed only those sorts which years of experience in growing and selling Geraniums has taught us are the very best in their different classes, such as can be depended on to produce the most satisfactory results and which represents the highest standard of development yet obtained in their special class and color.

In keeping this list up to this high standard we are constantly adding many of the newer sorts and discarding some of the old sorts which have been favorites but are now superseded by others which are more beautiful in form, greater in substance, more exquisite in color and more satisfactory in growth.

$$
20 \text { cents each. } \quad \$ 2.00 \text { per doz. } \quad \$ 10.00 \text { per I00. }
$$

ABBIE SCHAFFER-A beautiful soft pleasing crimson scarlet, in fact, the finest and most dependable Red we have; splendid semi-double flowers, magnificent trusses, abundantly produced; excellent semi-dwarf habit. A variety that is good everywhere.

ALPHONSE RICARD-A geranium of such perfect habit that it has become the standard by which all other geraniums are judged. The handsome perfectly formed, semi-double flowers of a bright vermilion scarlet are produced in profusion and the foliage is a handsome, luxuriant, bright green, slightly zoned. It is in every respect a general favorite.

BEAUTY POITEVINE-One of the most popular varieties that we have. With its lively light salmon color, its semi-dwarf, robust and branching habit, beautiful deep-zoned foliage, healthy constitution, perfectly formed flowers and enormous trusses freely produced. It is a variety that can be depended on.

BERTHA de PRESILLY - A most beautiful shade of silver rose pink, slightly shading to an almost white center; large semi-double flowers, profusely produced in splendid trusses, handsome light green foliage. One of the best bedding pinks we have, standing the sun well.
COL. THOMAS-One of the best among recent introduction. Distinct in color and exceptionally attractive, the color being a pleasing shade of deep, cardinal red and apparently covered with purplish sheen, deepening toward the center of the large, well-formed flowers, which are borne in long trusses; the habit is ideal; dwarf, vigorous and branching.

COUSIN JANIE-Dwarf, compact grower; very free flowering; exceptionally fine as a pot plant; small, light green foliage; semi-double flowers of a pleasing clear pink, slightly spotted red, gradually shading to a white center.

DAGATA-One of the most distinct and handsome pink geraniums we have, the foliage attains a magnificent size. It is that exquisite rich green which is so much admired by the most discriminating trade; the color is a strikingly beautiful shade of mauve rose, with large blotches of white at the base of petals; the trusses are gigantic and produced in profusion. 


\section{GERANIUMS-Continued}

DOUBLE DRYDEN-An ideal fancy pot plant as well as a good bedder. In color it is an attractive combination being coral white at the center, shading through delicate lilac toward the outer edge of the petals, which are a beautiful glowing soft crimson; flowers and trusses of a good size.

EDMOND BLANC-One of the newer standard geraniums that is attracting attention wlierever seen on account of the handsome coloring being the most beautiful of the cerise shades. The color is a bright carmine shaded around the white eye and on upper petals with bright scarlet. The flowers are perfectly formed in large trusses, which are freely produced, foliage deep rich green, slightly zoned.

E. H. TREGO-One $f$ the most beautiful shades of dazzling scarlet with an exquisite soft, velvety finish on a saffron ground. The flowers large semi-double and often measure 2 inches in diameter produced in enormous trusses in great profusion. The foliage is glossy green, with dark zone, large and of good texture; an excellent semi-dwarf, robust and branching. An ideal pot variety.

GENERAL GRANT - A universal favorite as a bedder; bright orange scarlet flowers profusely produced during the entire season in medium size trusses; a vigorous grower standing the sun exceptionally well.

JEAN OBERLE-One of the most beautiful among the colors known as peach pink, shading tenderly to almost pure white on outer edge of each petal; the florets are exceptionally well formed; immense trusses; habit usually strong and vigorous, very free bloomer; foliage distinct and one of the types that stand the sun well.

JEAN VIAUD_An attractive bright, clear shade of mauve rose, shading to a distinct white center; flowers are large and trusses enormous sometimes measuring 6 inches in diameter; habit dwarf, compact vigorous and exceptionally free flowering.

LA FAVORITE-One of the finest double whites in its class; pure in color, flowers of an enormous size. A continuous bloomer, the plant being covered with flowers the entire season, beautiful foliage; finest habit; unsurpassed as a bedder.

LA PILOTE-Brightest vermilion scarlet; an excellent grower and a profuse bloomer; foliage deeply zoned. A magnificent and striking variety and splendid for pot culture.
LEON BAUDRIER--Semi-double Cyclops. Immense semi-double flowers, large full trusses, freely produced on long rigid stems; foliage thick and leathery texture, habit of growth robust and branching. Colors a beautiful shade of carmine lake, shading soft cerise to a large white center. A most excellent fancs pot plant.

LEPOLD BOUILLE - Semi-double Cyclops; bright solferino red, upper petals richly shaded carmine purple to a distinct white throat; profuse bloomer; flowers large of perfect form and borne in large trusses; habit is ideal. Like all the superb cyclops this will, within a short time, become universal and an indispensable favorite. Exceptionally good for pot plants.

M. A. ROSELEUR-A most beautiful shade of Neyron rose. The flowers are large, semi-double, showing a distinct white center; enormous trusses borne on long, stiff stems well above the clean, extremely handsome foliage. In habit of growth it is the most pleasing semidwarf, short jointed and vigorous. We unhesitatingly recommend it, as there is no question but what it will give satisfaction in every case, either as a pot plant or bedder.

MARQUIS de CASTELLANE-One of the most beautiful and distinct geraniums in the Bruant class. Beautiful soft crimson, varying to tomato red. The flowers are very large, perfect in form and borne in large trusses, profusely produced on long rigid stems; foliage large and of fine heavy texture, slightly zoned habit, semi-dwarf and vigorous; strong constitution. A variety which we can recommend, knowing that it is one of the healthiest growers that we have.

MARQUIS de MONTMORT-Deep crimson carmine. A very novel and beautiful shade; fine large trusses and florets held well above the strong, robust deepzoned foliage. An exceptionally striking variety greatly admired.

MISS F. PERKINS-An exquisito shade of deep rose pink, with a distinct white throat; large handsome flowers and trusses borne on long, stiff stems held well above the foliage; well known standard favorite as a bedder or pot plant; constant bloomer, being a mass of color the entire season; strong constitution, standing our extreme climate condition. in fine shape. 
MAD. BARNEY-A profuse bloomer of enormous semi-double flowers of beautiful deep pure pink, grand dwarf and branching habit, a perfect bedder and splendid pot variety.

MAD. BUCHNER-Strong vigorous grower produing magnificient snow white flowers. Beautiful foliage.

MISS KENDALL-Dark carmine red shading to geranium lake towards the center of the bold, round full flowers of fine form; trusses large and strikingly handsome; strong, vigorous grower; dark rich green, deep-zoned foliage; slightly zoned.

MME. CANOVAS-Very dark velvety scarlet, with maroon shading; immense florets, produced in large trusses on long stems held well above the foliage. A rival to S. A. Nutt in color but a stronger grower.

MME. CHARROTTE-Flowers are large semi-double and perfect form; trusses enormous, produced in great profusion on good long stems throughout the entire season; habit is dwarf, robust and vigorous; foliage heavy deep green, broad chocolate zone. The color is a clear distinct salmon shading lighter toward the outer edge; unexcelled as a pot plant; id splendid bedder.

MME. F. SARLOVEZE - An exquisite and pleasing shade of light rose, shading to a white center; the immense and semidouble flowers are very attractive; dwarf and branching in habit and growth.

MME. JAULIN-Floweres are very large, produced in enormous trusses, semidwarf and compact grower. The foliage is large, handsome and deeply zoned; flowers large; trusses immense and freely produced; color an exquisite shade of rich, light salmon, shading lighter to an almost white margin at edge of petals.

MME. LAPORTE BISQUE - A very strong, robust, semi-dwarf and compact grower. The foliage is large, handsome and deeply zoned; flowers large; trusses immense and freely produced; color an exquisite shade of rich light salmon, shading lighter to an almost white margin at edge of petals.
MME. LANDRY-One of the choicest and handsomest of the Bruan' race, very free and constantly in bloom throughout the season; florets are large and borne in enormous trusses on long stems held well above the foliage. Color is a brilliant shade of apricot shading to a copper with white eye; in habit it is robust, semidwarf and a vigorous grower; broadfluted, slightly zoned foliage; evidently the best white we have.

MONSIEUR EMILE DAVID - Strong, healthy, erect growth of luxuriant glossy green foliage; trusses enormous dimension; immense semi-double flowers of a violet rose color with base of upper petals feathered white; freely produced on long stiff stems. Unsurpassed as a bedder.

MME. RECAMIER-Pure white; individual flowers are double, beautifully formed and produced in enormous trusses; strong and vigorous grower; broad-fluted, slightly zoned foliage; evidently the best white we have.

MRS. ANNIE VINCENT-Exqusite semidouble flowers of a pure carmine color somewhat maculated white; incomparable for freshness and brightness; short, robust grower, with exceptional resistance to inclement weather. The handsome semi-double flowers are produced in magnificent trusses well above the attractive foliage.

MRS. LAWRENCE-This is one of the finest geraniums that we have in this color. Clear, healthy foliage; splendid dwarf, compact habit of growth; wonderfully free in flowering; indispensable as a pot plant, being strongly recommended as a flower for winter; unsurpassed as a bedder. The color is an artistic shade of satiny salmon pink, slightly tinged white.

ORNELLA - A continual bloomer; beautiful semi-double, deep rich scarlet flowers, slightly shaded crimson; excellent habit, splendid truss and foliage. A magnificent variety, which we are confident will meet the requirements of any semidouble scarlet geranium. Luxuriant both as a pot plant and a bedder.

PETER HENDERSON-A perfect specimen of the Bruant or sun proof type, foliage of excellent texture, strong robust grower. The bright poppy red

flowers are freely produced, an all around good red Geranium. 


\section{R.Vincent, Jr. \& Sons Co.}

\section{GERANIUMS-Continued}

PRESIDENT BAILLET-This variety represents the true Bruant type. Beautiful, heavy, luxuriant, slightly zoned foliage; strong, robust grower, enormous trusses of semi-double flowers freely produced; color a bright scarlet, with a soft velvety finish; strong, healthy constitution, standing the sun well.

S. A. NUTT-A dark red geranium. Considered to be one of the best bedders and is more generally used than any other geranium, both as a pot plant and a bedder. A vigorous compact grower, with clean, healthy constitution.

SCARLET BEDDER-A rather dwarf, compact grower; medium size, deep-zone foliage; free flowering, fair trusses of perfectly formed semi-double flowers; dark, fiery red color, not as dark as S. A. Nutt; magnificent as a pot plant, as well as a bedder.

\section{Single VARIETIEs}

ADMIRATION-A strong robust grower, with bright rose shrimp-pink flowers, shading to a white center, a profuse bloomer; enormous trusses of beautifully formed flowers.

ALICE OF VINCENNES-A very distinct and pleasing combination of color; white ground with a charming graduation of shades from white throat through a beautiful shade of violet crimson to an immense scarlet margin.

ANTITHESIS-Large, round flowers of vermilion scarlet, with a large spot on upper petals; grand contrast of color; very floriferous, robust, compact grower.

ARDENS-Excellent large flowers and trusses of a beautiful and attractive shade of vermilion scarlet, with a distinct white throat; fine habit of growth.

CHARLES GUERIN-Round flowers of a salmon carmine color, white eye, enormous trusses; flowers are perfectly formed; a most profuse bloomer.

CLARIE ALBANE-Large flowers of pure white; strong constitution enabling it to withstand summer heat extremely well. An excellent variety.

CLIFTON-A handsome dark, velvety, deep scarlet with maroon shading, vigorous, compact grower; well formed flowers, produced in enormous trusses. Clean, healthy constitution and stands the sun well.

COUNT ZEPPELIN-An excellent bedding variety. Most attractive and beautiful shade of light vermilion; dwarf, compact grower; shape and habit of growth all that can be desired in an ideal pot plant. A decided acquisition to any collection.

COMMANDANT OTT - An extremely handsome variety, having beautiful flowers of a shade of aniline red, with large white center; fine habit of growth; large trusses.
EMMANUEL ARENE-Immense trusses, well-formed flowers, of a deep rich velvet crimson, maculated orange red.

EUGENE SUE-A very attractive and brilliant shade of russet orange; immense foliage of fine texture; floriferous effect of this variety is incomparable; semi-dwarf; robust and branching habit.

FEUER - A variety that was very highly recommended when it came into our possession and it has not disappointed us. It is a continuous yielder of a brilliant crimson-red flower; dwarf, compact grower.

GABRIEL MONTOYA-A strong robust grower of most exquisite reddish-purple flowers; a distinct and attractive shade; continual bloomer; very large irusses.

GRANVILLE-An excellent bedding variety; most attractive shade of deep-rose pink, with white blotches on upper petals; desirable, strong, compact and beautiful habit, standing the sun extremely well.

JEAN PABON-Robust and free flowering; the trusses are enormous and held well above the foliage. Grand round flower, blood red color, small white eye; good strong robust grower; clean, healthy constitution.

JACQUERIE-A most beautiful shade of deep carmine red, immense trusses on exceptionally long stems; very vigorous grower and unsurpassed as a bedder.

JUSTE OLIVER - A peculiar and pleasing shade of carmine purple, upper petals shaded fiery red; a unique and beautiful color for bedding and massing.

KONIGEN OLGA WURTEMBERG-An old, popular bedder; dwarf grower, exquisite shade of deep rose, white at base of petals; a profuse bloomer, flowers being produced at every joint; unsurpassed as a bedder. 
GERANIUMS-Continued

L'AUBE-Excellent trusses and flowers of pure snow white. One of the best single whites of this class, retaining its purity the entire season; an excellent pot plant.

MARGUERITE de LAYR - Continual bloomer; pure white flowers. Attractive, pleasing variety; enormous trusses, freely produced on long rigid stems.

MAXIME KOVALESKI-Fine, vigorous growe r; handsome foliage; beautiful orange shade of Lincoln red; a very distinct and striking variety when massed; a great acquisition to bedding class.

MLLE. ANATASIA LACADRE-Immense trusses and flowers of a rich crimson carmine shading through a maculated effect to a pure white center; handsome deep-green foliage of fine substance; unsurpassed as a bedder.

MME. MOSNAY - Perfectly forme $r$ flowers of a magnificent $\mathrm{sh}$ a de of geranium red, upper petals shaded violet to a white center; flowers produced in enormous trusses on long rigid stems; handsome deep-green foliage; unsurpassed as a bedder.

MRS. E. G. HILL-An exquisite shade of soft, light salmon, continual bloomer; excellent bedding variety; semi-dwarf; wili resist the heat of the sun.

MRS. E. RAWSON - Extraordinarily strong and vigorous grower of immense semi-dwarf bright scarlet flowers, with crimson shading on upper petals; capable of withstanding the extreme summer heat; excelient for bedding.

PAMELA-This is a variety that is universally admired; immense rounds of flowers with a pure white center shading through a maculated effect to a broad, distinct, outer margin of crimson lake; an exceptionally strong, vigorous grower for an English round flower sort.

PAUL CRAMPE - Attractive shade of vermilion scarlet; deep rich green, distinctly zoned foliage; strong, compact, vigorous.

PRINCESS ALEX-Large and perfect flowers of a most pleasing shade, of bright carmine lake, produced freely in grand trusses. An exceptionally fine pot plant.
RIVAL-A result of a cross between Zonal and Ivy-leaved type, retaining more of the nature of the Zonal and possessing many of the good points of both parents. Splendid as a pot plant and under favorable conditions is an excellent bedder. Color a unique soft shade of salmon red, upper petals beautifully blotched.

ROSALDA-Extremely handsome flower of a rich crimson pink, upper petals heavily blotched white and pencilled crimson; a true representative of the Bruant race.

SNOWDROP-Stron , compact grower; splendid bedding variety, having enormous trusses of pure white flowers, held well above the foliage. A variety that will not fade.

SYCAMORE-An attractive shade of salmon pink; profuse bloomer; very large flowers produced in enormous trusses on long rigid stems; strong vigorous grower of good habit.

TEODOR de WYZEWA-Cheerful clear shade of a clear lilac rose, with blotch on upper petals; strong branching, semidwarf grower, of beautiful flowers and trusses abundantly produced.

TELEGRAPH-Mammoth, dark green, slightly zoned foliage; strong robust grower, having an iron-clad constitution and stands the sun with perfect immunity; enormous flowers and trusses of beautiful Lincoln red.

THE SIDAR-Magnificent round flowers of an exquisite shade of intense scarlet; large trusses produced on long rigid stems, making a very attractive variety.

TIFFIN - One of the finest blooming single varieties; flowers of an attractive shade of rich, glowing scarlet; crimson shading on upper petals.

VICTOR GROSSET-Continual bloomer; excellent truss and flowers of a bright rich shade of apricot salmon, bordering on vermilion scarlet; splendid bedder, excellent habit; strong, healthy constitution.

\section{Ivy Leaved Geraniums}

ALPHA-The foliage is finely denticulated. The center of the leaf is greenish maize, with a broad dark zone, edged golden yellow; free flowering, of a rich shade of scarlet red. A single medium size, abundantly produced in fair size trusses.
ACHIEVEMENT-Distinct and pleasing shade of soft cerise pink; immense semidouble flowers, freely produced in large trusses; capable of withstanding inclement weather because of the hardness of its strength, the result of a cross with Zonal. 


\section{GERANIUMS-Continued}

ALLIANCE-A French hybrid etween a Zonal and Ivy. Its color is a most exquisite shade of delicate, lilac white, upper petals feathered and blotched bright crimson rose; flower's semi-double and abundantly produced in fine, large trusses; foliage beautiful, clean and of splendid leathery texture; habit excellent, robust, strong, close-jointed.

BALLADE-Large semi-double flowers and trusses of a magnificent shade of tender lilac, upper petals feathered with crimson maroon; a strong, steady grower, of splendid habit; a fine pot plant.

BETTINA-Superior, semi-double flowers and trusses of a magnificent shade of tender lilac white, center of petals and flowers being blotched with Tyrian rose; remarkable as a pot plant; dwarf, compact habit.

CAESAR FRANCK-One of the most popular ivy geraniums yet introduced, the color is an attractive shade of soft, rich crimson, with an exquisite shading of tender rose at the base of petals; habit vigorous, quick growing and pleas ing; strong constitution.

COLONEL BADEN POWELL-Flowers of enormous size, one of the largest among the Ivies, abundantly protuced in good size trusses; semi-double of elegant showy form; color varies at times from pearl white to soft blush.

GORDENS GLORY - Flowers of good quality and large size; pleasing and attractive for fancy baskets or vases; a profuse bearer of a beautiful bright scarlet flower, which is considered to be one of the best of its type.

COUNTESS de GREY-Profuse bloomer; large well-formed flowers; a pleasing light satiny salmon color; foliage and petals of fine durable substance; strong, healthy, erect growth; luxuriant glossy, green foliage.

HECTOR GALCOMELLE-An exquisite shade of lavender white, effective tinted pale rose, upper petals distinctly feathered, crimson maroon, lower petals touched with same color; large semidouble flowers, splendid habit of growth.

INCOMPARABLE-Very large trusses; florets immense and regular in form; a beautiful variety and exquisite shade of rose carmine; d w a $\mathrm{f}$ bold, compact grower.
JAMES ATTFIELD-A hybrid, extra large, double flowers of a pretty tint of soft pink, short jointed in growth; very free.

JAMES T. HAMILTON-A hybrid; intense carmine crimson; long stout stems; good for bedding or pot work.

JOSEPH WARREN - A distinct and striking variety; large bold, semi-double of good substance; lovely rich purple, rose color, slightly feathered dark maroon.

MME. THIBAUT-Magnificent shade of clear rose pink, upper petals delicately but distinctly feathered deep crimson maroon; immense trusses, undulated petals; strong, vigorous habit; luxuriant waxy foliage.

MRS. BANKS-Flowers are large, semidouble and borne in medium size trusses on long wiry stems; color a pleasing shade of blush white, upper petals feathered reddish Neyron; in hapit of growth it is truly an ivy; exceptionally strong and vigorous, flowering abundantly through the winter; handsome light green foliage.

MRS. HAWLEY - Pleasing shade of rose cerise, slight magenta shadirg, dark blotch on upper petals; large semi-double flowers; strong, robust grower; splendid habit.

PIERRE CROZY-Profuse jloomer; large semi-double flower's, color bright scarlet, handsome and delicate finish; open trusses; possesses all the good qualities, which make up an ideal pot plant; low growing bedder; very heavy in texture while forms of truss and florets are found only among the ivies.

RYCROFT SURPRISE - Semi-dwarf, short jointed and branching habit of growth. One of the most beautiful and best ivy geraniums that we have. In color it is a charming clear rose-a rich pink which is very attractive. Combining all these qualities, it makes an ideal ivy geranium.

SCARLET CROUSSE - A magnificent shade of cardinal red; fine full flowers, large trusses; splendid free, bold habit, deep green foliage of fine substance; very effective.

SOUV. de CHAS. TURNER-Deep pink feathered maroon on upper petals; individual florets $2 \frac{1}{2}$ to 3 inches across. 


\section{GERANIUMS-Continued}

\section{Scented Leaved Varieties}

BALM-Large flowers, upper petals light lilac, lower petals dark; large leaves with very strong fragrance.

CAPITATUM - Small cut leaf; rose scented.

CLORINDA - of splendid, free bold, growing habit; deep-green foliage and an agreeable and refreshing fragrance. Flowers of good size and quite an improvement in that respect; of a bright rose cerise $\mathrm{shade}$; splendid winter bloomer; very free flowering.

DR. LIVINGSTON-This is the so-called skeleton leaved geraniums; leaves freely cut or fern-like; strongly fragrant.

DALE PARK BEAUTY-Pleasing and fragrant foliage; immense flowers, broad lower petals deep lilac, upper petals purplish crimson maroon, feathered dark maroon.

FAIR ELLEN-Large oak-leaved follage; fragrant and beautiful.

FELICIFOLIUM ODORATUM.-Very attractive on account of its beautiful fernleaf foliage, both as a plant and when used among flowers; a great favorite.
LADY MARY-Upper petals, rose-lake shaded violet crimson; lower petals blush white, small flowers, very pleasing odor.

LEMON-Small, glossy green leaves: delicate lemon scented.

MRS. KINGSBURY-Magenta crimson, shading lighter to a white eye; upper petals vein ed maroon; sweet-scented foliage.

NUTMEG-Nutmeg fragrance: dwarf light green foliage. Introduced 1774.

OAK LEAVED-Leives somewhat resembling those of an oak tree, dark chocolate center.

PHEASANT'S FOOT-Large foliage.

QUERCIFOLIUM - Oak-leaved foliage, leaf black center, very attractive.

ROSE-The standard rose scented: a favorite since it was introduced.

SCHOTTESHAMPET_Filbert scented.

TOMENTOSUM-L.rge, flat woolly foliage, highly scented with peppermint.

\section{FUCHSIAS}

Fuchsias are much prized as pot plants for both winter and summer blooming. They are of a hard-wooded nature and can be kept for any number of years, in fact, can almost be grown into small trees. The flowers are bell-shaped, held in graceful sprays. In the summer they should be kept out of the hot sun; are unexcelled for shady porches.

$$
20 \text { cents each. } \quad \$ 1.5^{\circ} \text { per doz. } \quad \$ 8.00 \text { per IOO. }
$$

A. P. VITAL-Plum color.

BANJADI-Tube and petals rose cerise, corolla dark plum.

BLACK PRINCE-Single. Purple striped with red, red sepals.

BERANGER - Violet purple.

CONVENT GARDEN WHITE - White tube, red corolla.

ELM CITY - Calyx of cochineal red, large single corolla of deepest red.

EDMOND ABOUT - Semi-d uble, white corolla, deep pink petals and tube.

E. REMAN - Pink corolla with white petals.

ELEGANS-Sepals white, corolla clear rose.

FELICIEN DAVID-Sepals red, carmine, corolla plum.
GRAFF WITTE-Red corolla, red sepals.

GERBERT-Curved petals, fiery red. Large double corolla, reddish purple blotched cardinal red.

JEANNE D'ARC-Tube and petals white, corolla rose carmine.

JULIUS LEJEUNE-Plum streaked rose.

J. MORNS-Double rose.

LACEDEMORNE-Large. double white.

LUCIENNE BREVAL-Sepals red carmine, large corolla.

MARINKE - Red flo:vered, tall grower.

MINNESOTA - Tube and petals light pink, corolla violet purple.

MINISTER BOUCHER - Double. Large carmine petals, lilac rose corolla.

MRS. GLADSTONE-Double white corolla, scarlet tube and petals. 
PRINCE GEORGE-Double, volet prunecolor.

PATRIE-Double white.

SOUV. de H. HENKEL-Metallic bronze, large cinnabar red flowers.

\section{HARDY ENGLISH IVY}

A Hardy Evergreen Vine that retains its dark glossy leaves all the year. It is one of the most valuable of all Hardy Vines, extensively used in covering walls, to which it will cling if it has a rough edge to which it can root. It has also become popular for covering graves, holding terraces, etc.
20 cents each.
\$I.5O per doz.
$\$ 8.00$ per IoO.

\section{HELIOTROPE}

Heliotrope has long been a favorite garden plant on account of the delightful fragrance of the flower, which can be used advantageously with any other flowers lacking fragrance of their own. The finely formed delicate lavender color of the flowers harmonizes with most any other color. The varieties we offer have been selected with great care.

$$
20 \text { cents each. } \quad \$ 1.50 \text { per doz. } \$ 8.00 \text { per IoO. }
$$

CHIEFTAIN-Lilac, sweet scented.

MME. BRUANT - Very dark purple.

Large trusses.
MME. de BLONAY - Large trusses, nearly pure white.

\section{LANTANAS}

There are few summer flowering plants that give more satisfaction than Lantanas. They can be depended on to bloom regardless of the hot sun and dry weather if given any chance at all. They are becoming quite popular as a bedding plant on account of their bright, showy colors, running through scarlet, yellow, pink and lavender. The Delicatissima, or Weeping, is hard to surpass as a basket or vase plant.

$$
20 \text { cents each. } \quad \$ 1.50 \text { per doz. } \quad \$ 8.00 \text { per } \text { Ioo. }
$$

A. CLAVEAN-Primrose pink.

A. COOK-Orange and ruse-dwarf; compact grower.

AURORA - Tall, orang:e and coppery red. DELICATISSIMA, OR WEEPING-Lilaclavender; one of the finest basket plants that we have.

E. BAYARD-Bright orange, red and yellow.

CRAIGI - Lemon yellow turning to orange.

HARKETT PERFECTION - Variegated foliage; light pink and yellow.

HELVIA-Pale canary, shading to a deep yellow center.
IOLANDO-Rich orange, shading to a bright red; semi-dwarf.

JUAN D'OR-Bright sulphui, shading to a deep rose pink.

LA PLUIE D'OR - Pure yellow, dwarf grower.

LEO DEX - Open orange s.arlet, changes to dark maroon; robust.

LYRE-Pure white with yellow centre; large flowering.

MER JAUNE-A beautiful semi-dwarf variety; bearing in profusion golden yel low blossoms.

ORA-Pure white. 


\section{LANTANAS-Continued}

PICTAVI-Semi-dwarf; free; a lovely rose-colored umbel, shading to orange in centre.

PROTEE-Old rose and golden yellow.
RADIATION-A grand combination of color, brilliant and red shading.

VIATOR-Large flowers, sulphu, yellow, tinged pink.

\section{LEMON VERBENAS}

A well-known garden plant, appreciated for the sweet lemon-scented foliage, which is extensively used to impart a sweet scent to bunches of flowers lacking in a scent of their own. It is also used in flavoring jellies.

$$
20 \text { cents each. } \quad \$ \text { I.50 per doz. } \quad \$ 8.00 \text { per Ioo. }
$$

\section{LOBELIA}

Splendid bushy little plants, growing about six inches high, with fine foliage. The plant becomes covered with deep indigo-blue wing-shaped flowers, at times almost completely hiding the foliage. Useful for low borders in semi-shady places, or hanging baskets and window boxes, doing best when protected from the hot sun.

CRYSTAL PALACE GEM- $\$ 0.20$ cts. each. $\$ 1.50$ per doz. $\$ 8.00$ per 100

\section{MOONVINES}

A quick growing vine, having rich green foliage; one of the best vines that can he had for covering porches, etc. The beautiful, pure, large white flowers when open in the evening produce an effect which almost baffles description. The flowers of I.eari are a most beautiful blue. They remain open well into the morning.

$$
20 \text { cents each. } \quad \$ 1.50 \text { per } \text { loz. } \quad \$ 8.00 \text { per Ioo. }
$$

NOCTIFLORA - The standard white LEARI-(Blue Dawn Flower) Generally Moonvine. known as the Blue Moon Flower.

\section{PETUNIAS}

The Petunia has long been a favorite summer flowering plant for the garden or porch boxes. They are continually in bloom from early spring until late Fall. We have for a number of years made a specialty of these and offer a select variety of colors.

$$
20 \text { cents each. }
$$

DOUBLE FRINGED MIXED. SINGLE FRINGED MIXED.

$$
\text { \$I.50 per doz: } \quad \$ 8.00 \text { per IOO. }
$$

ROSY MORN-Soft carmine pink with white throat. A favorite for basket window boxes, etc.

\section{SAGE}

Holt's Mammoth. Broad leaved, strong growing; used extensively for flavnring. This variety is propagated from cuttings; it very seldom seeds.

20 cents each.
$\$ 1.50$ per doz.

$\$ 8.00$ per" $^{\prime \prime} 100$. 


\section{R.Vincent, Jr. \& Sons Co.}

\section{SALVIA-Bonfire}

The popular Scarlet Sage, growing from 18 to 30 inches high; covered the entire summer with sprays about five inches long of the highest scarlet, producing a color effect that can be seen as far as the eye can discern; superior as a bedding plant or border for tall growing Cannas, planting in front of a porch, etc.; stands the sun perfectly.

$$
20 \text { cents each. } \quad \$ 1.50 \text { per doz. } \quad \$ 8.00 \text { per Ioo. }
$$

\section{SENECIO SCANDENS}

\section{(Parlor Iz'y)}

Parlor, or German, Ivy, a fast growing vine, with bright green, luxuriant foliage, especially suitable for trellis work, conservatories, hanging baskets or in porch boxes, etc., where the wind does not strike it too hard.
20 cents each.
$\$$ I.5O per doz.
$\$ 8.00$ per $^{-100 .}$

\section{SAXIFRAGA SARMENTOSE}

Strawberry Geraniums, a low growing plant, with leaves nearly round, striped freely with silver veins. It is adlapted to hanging baskets and boxes; makes one of the most handsome plants imaginable when growing in a basket with the young plants drooping down held only by a thin, wiry stem.

$$
20 \text { cents each. } \quad \$ 1.50 \text { per loz. } \quad \$ 8.00 \text { per } 100 .
$$

\section{SW ANSONIA}

Galegifolia Alba. A native of Australia, bearing a profusion of sprays of white flowers resembling Siveet Peas; will bloom all winter, and when the beautiful lacelike foliage can be trained over a window box it produces an effect that is very pleasing.

$$
20 \text { cents each. } \quad \$ 1.50 \text { per doz. } \$ 8.00 \text { per Ioo. }
$$

\section{TRADESCANTIA}

The Wanclering Jew. A variegated plant of easy and rapid growth, very easily propagaterl. The plant should have plenty of moisture; usually used in hanging baskets, porch boxes, etc.

RED - Red and green striped. 20 cents eacl.
BICOLOR-White and green striped. $\$ 1.50$ per doz. $\quad \$ 8.00$ per Ioo.

\section{VINCA}

Variegated Periwinkle. A beautiful white and green variegated trailing vine, admirably adapted to window boxes, hanging baskets and vases.
20 cents each.
$\$$ I.50 per doz.
$\$ 8.00$ per 100. 